Mavi Atlas, 5(1)/2017: 22-43. Araştırma Makalesi | Research Article

Makale Geliş | Received: 20.03.2017

Makale Kabul | Accepted: 04.04.2017

Doi: 10.18795/gumusmaviatlas.304356

\title{
Celal YEŞILÇAYIR
}

Yrd. Doç. Dr. | Assist. Prof. Dr. Gümüşhane Üniversitesi, Edebiyat Fakültesi, Felsefe Bölümü, Gümüşhane-Türkiye Gümüşhane University, Faculty of Letters, Department of Philosophy, Gümüşhane-Turkey

cyesilcayir@gumushane.edu.tr

\section{Carl Schmitt'in Liberalizm Eleştirisi}

\section{$\ddot{O} z$}

Siyasi düşünce tarihine bakıldığında, dönemin popüler siyasal paradigmasıyla barışık filozofların yanında, bu düşüncelere itiraz ederek farklı bir teori ortaya atmaya çalışan düşünürler olduğu da görülmektedir. 20. yüzyılın ilk yarısında Avrupa'da yaygınlaşan siyasi anlayışlara en radikal eleştiriyi yönelten düşünür belki de Carl Schmitt'tir. Onun eleștirilerinden en büyük nasibi șüphesiz parlamenter demokrasi, çoğulcu ve liberal teoriler almaktadır. Bu makalede, onun liberal siyasi teorilere yönelttiği eleştiriler niçin ve nasıl soruları bağlamında ele alınmaktadır. O, dönemin siyasi oluşumundan hareketle çoğulcu ve liberal teorilerin yaşanan siyasal/sosyal sorunların temel nedeni olduğuna inanmaktaydı. $\mathrm{O}$, eleștirilerinde, s1k sık düşünce tarihine yönelerek felsefi temellendirmelere başvurmayı da ihmal etmez. Başlıca ilham kaynakları ise Hobbes ve Hegel'in siyaset felsefeleridir. Bununla birlikte Schmitt'in nasyonal sosyalizmle olan tartışmalı ilişkisine çalışma içinde yer verilecektir.

Anahtar Kelimeler: Weimar Cumhuriyeti, Parlamenter Demokrasi, Liberalizm, Sivil Toplum.

\section{Carl Schmitt's Critique of Liberalism}

\begin{abstract}
Having looked at history of political opinion, in addition to pilosophers who is defender popular political paradigm of that period, there are philosophers who objects to that view trying to suggest alternative theory. The first half of 20th century Carl Schmitt is one of thinkers criticising radically to political view widespried in Europa. Undoubtedly, he criticises mainly parliamentary democracy, pluralistic and liberal theories. In this paper, his criticisms raised againist liberal political theories are discussed in the context of why and how questions He, with reference to political formation in that period, believes that pluralistic and liberal theories were to blame for politic/social problems. He does not ignore apply to philosophical justification frequently keeping in mind history of philosopyh in his criticisms. His primary sources of inspiration are political philosophies of Hobbes and Hegel. In addition to this, problematic relationship between Schmitt and national socialism is dealt with in that paper.
\end{abstract}

Keywords: Weimar Republic, Parliamentary Democracy, Liberalism, Civil Society. 


\section{Giriş}

Düşünce tarihi incelendiğinde, genel anlamda fillozofların yaşadıkları dönemin sosyal ve siyasal sorunlarına kayıtsız kalmadıkları görülmektedir. Şu halde düşünürlerin fikirlerini daha iyi anlayabilmek için eserlerini kalem aldıkları devrin tarihi ve sosyolojik şartlarını göz önünde bulundurmak gerekmektedir. Bununla birlikte onların eserlerinden hareketle yaşadıkları zamanda cereyan eden gelişmeler hakkında bilgi sahibi olmak da mümkündür. Sözgelimi Kant, Fransız İhtilali’nin oluşturduğu havadan aldığ1 cesaretle cumhuriyetçi düşünceler ileri sürmüştür (Yeşilçayır 2017: 85). Öte taraftan öğrencisi Fichte, ülkesinin içinde bulunduğu ekonomik krizden kurtulması için kapalı ticaret devleti modeli adı verilen bir teori ortaya atmıştır (Topakkaya 2011: 181). Geçen yüzyılın önde gelen siyaset ve hukuk felsefecileri arasında gösterilen Carl Schmitt ise yaşadığı çağın siyasi gelişmelerini iyi analiz eden eserler kaleme almıştır. Yaşadığı ülkenin içinde bulunduğu sosyal, siyasi ve ekonomik sorunları iyi analiz etmesinin yanında o, bu sorunların çözümüne yönelik ileri sürdüğü fikirlerin entelektüel kalitesi ile de adından söz ettirmiştir.

Schmitt'in düşüncelerinin teorik boyutunun oluşumunda öncelikle Hobbes'un siyaset felsefesinin etkisi hissedilmektedir. Hobbes'un Leviathan'da ele aldığ 1 düşünceler ise özellikle yaşadığı ülkede ortaya çıkan iç savaş ve kargaşanın tesiriyle şekillenmişti (Topakkaya 2016: 133). Onun ülkenin yaşadığı çalkantıdan kurtulması için ortaya attığı mutlak güçlü lider modelinin 20. yüzyıl versiyonunu Schmitt'in siyaset felsefesinde okumak mümkündür. Ancak onun Hobbes ile arasındaki benzerlik bundan çok daha fazladır. I. Dünya Savaşı'ndan sonra kurulan Weimar Cumhuriyetinin siyasi ve ekonomik anlamda krizde olmasından dolayı o, Leviathan motifine benzer şekilde güçlü lider etrafinda bütünleşmiş, ulusal bir devlet modeli öneriyordu. Söz konusu yeni devlet modelinin siyasi yapısını belirleyen temel unsurların ise ülkenin tarihsel, kültürel ve sosyolojik özellikleri olması gerekiyordu. Schmitt'e göre ülkeler başka ülkelere benzeyerek değil ancak kendi kimliklerini belirgin hale getirerek güçlü ve bağımsız olurlar. 
Öyle ki çoğulcu ve liberal teoriler devletleri ancak pasifliğe ve kargaşaya sürüklerler. Bu bağlamda onun referans kaynağı olarak ikinci önemli ismin Hegel olduğunu söyleyebiliriz. Hegel'in siyaset felsefesinde kendi bilincinde olma anlayışının ulusların temel karakteristiğini oluşturması gerektiğini savunması (Hegel 2004: 211; Kervegan 1988: 372) Schmitt için oldukça muteberdir. Bunun yanında Hegel, devleti kendi bilincinde cevher olarak onun dünyaya sağlam kök salmasının yolunun kendi tarih ve kültürünün bilincinde olmasına bağlı olduğunu savunuyordu (Topakkaya 2006: 190). Onun mezkûr düşüncelerinden etkilenen Schmitt, ulusal kimliğin belirleyici olacağı bir siyaset anlayışı benimseyecektir. Bununla birlikte halka doğru açılan çoğulcu bir teorinin aksine halkın ulusal bilincinden doğacak güçlü bir liderin ülkeyi içinde bulunduğu kriz durumundan çıkaracağına inanıyordu. Ayrıca Schmitt'in siyaset felsefesinde Hobbes ve Hegel'in fikirlerinin dönemin şartlarını iyi analiz edip çözüme yönelik fikirler oluşturmak için harmanlandığını söylememiz mümkündür.

Schmitt'e göre Weimar Almanyasının içinde bulunduğu söz konusu kriz durumunun baş müsebbibi liberal parlamenter siyasi yapıdır. Bununla birlikte o, yazılarında temel olarak Alman halkını, devletin içinde bulunduğu pasif tutum konusunda uyandırmaya çalışır (Çelebi 2014: 16). Ona göre devlet siyasi görevini yerine getirmekten aciz kaldığı için siyasi birliği sağlamak görevini başka kurumlar üstlenmeye başlamıştır. Schmitt'in nasyonal sosyalizm ve Hitler' in partisi olan NSDAP ile olan ilişkisi ise oldukça tartışmalı bir konu olarak karşımıza çıkar. Onun 1933’te söz konusu partiye üye olduğu ve bu üyeliğin yaklaşık üç yıl kadar devam ettiği bilinmektedir. Bunun yanında liberal teorilerin aksine onun önerdiği güçlü lider anlayışı, sonraları Hitler'in partisi NSDAP'ın da temel hedeflerinden biri haline gelecek ve Hitler, mutlak yetkilerle donanımlı bir şekilde Almanya'yı yönetecektir. Bu noktada acaba Schmitt'in önerdiği lider anlayışı Hitler'in şahsiyeti ile birebir tecessüm etmiş midir diye bir soru akıllara gelmektedir.

Kanaatimize göre Schmitt'i sadece nasyonal sosyalist bir yazar olarak değerlendirmek, onun düşüncelerini anlamak için yetersiz kalacağından onunla ilgili analitik yorumlar yapmak daha tutarlı bir yaklaşım olacaktır. Jürgen Seifert'a göre iki 
dünya savaşı arasında Almanya'da nasyonal sosyalizmin ve Hitler'in partisinin yükselişinin sorumluluğunu yükleyebilmek için ideal günah keçilerinden biri Schmitt olmuştur (Seifert 1985: 193). Çünkü Schmitt, yazılarından bazı cümleler alarak değerlendirilirse nasyonal sosyalist bir yazar olarak nitelenebilir ancak onun eserlerinin tamamı tarihi ve sosyolojik şartlar çerçevesinde analiz edilirse durumun farklı olduğu anlaşılabilir (Seifert 1985: 193). Diğer taraftan Schmitt'i çok fazla haksızlığa uğramış biri olarak tanıtmak kanaati de çok yerinde bir tutum değildir. Çünkü onun güçlü lider anlayışını bir siyasi model olarak savunduğu ve belli bir dönem mezkûr partiye gönül verdiği aşikârdır. Acaba Hitler'in ilerleyen dönemlerinde ülkeyi felakete sürükleyen hamleler yapacağını önceden biliyor olsaydı yine Schmitt'in onun partisiyle bir gönül bağı olur muydu diye başka bir soru daha akıllara gelmektedir. Zira mezkûr partiden ayrıldığı (ya da atıldığı) 1936 yılından sonra onun Nazilere yönelik alegorik ve üstü örtük eleştiriler yönelttiği kayıtlarına rastlanmıştır (Kardeş 2015: 27). Bu bilgiye istinaden onun NSDAP için önceki düşüncelerinin zamanla değiştiğine yönelik bir yorum yapmamız da mümkündür. Şu halde onun nasyonal sosyalizmle olan mesaisi muğlak ve spekülatif bir konu olarak kalacağa benzemektedir. Kanaatimize göre onu, Nazizmin fikir babası olarak yaftalayıp bir kenara bırakmak, siyaset ve hukuk felsefesi üzerine yazdığı ve ciddi felsefi temellendirmeleri içinde barındıran eserlerine haksızlık olacaktır. Dolayısıyla Schmitt'i bir bütün olarak değerlendirip onun çoğulcu teorilere ve liberal anlayışlara karşı yönelttiği eleştirilerin siyaset felsefesi bağlamında tartışılması gerektiği kanaatindeyiz.

Geleneksel liberal teoride devlet, bireysel özgürlükleri kontrol etmekle değil, onları korumakla mükelleftir. Bu çalışmada Schmitt'in yaşadığı dönemde yükselişe geçen liberal teorilere karşı yönelttiği eleştiriler incelenmektedir. Bu amaca yönelik olarak öncelikle onun siyaset antropolojisi hakkındaki düşünceleri ele alınacaktır, bunun üzerine onun söz konusu düşünceleri çoğulcu ve liberal teorileri eleştirirken nasıl işlediği irdelenecektir. Bunun yanında Schmitt'in söz konusu eleştirilerinde Hobbes ve Hegel'in fikirlerine nasıl ve hangi bağlamda başvurduğuna yer verilmektedir. Onun 
çoğulcu ve liberal teorilere yönelik tutumunu analiz etmeye, yaşadığı ülkenin siyasi atmosferine kısa bir yolculuk yaparak başlamamız yerinde bir tutum olacaktır.

\section{Weimar Almanyası ve Schmitt}

Aslında her eser/yazı kendi zamanının ruhunu yansıtır ilkesi Schmitt'in eserleri için daha belirgin bir geçerliliğe sahiptir. Çünkü o, kendi döneminde revaçta olan siyasi teorileri iyi tahlil etmek suretiyle bu anlayışlara olan itirazını açık bir şekilde ifade eder. Almanya'da I. Dünya Savaşı'nın kaybedilmesinden sonra Büyük Britanya ve ABD’nin etkisiyle kurulan Weimarer Republik (Cumhuriyeti), liberal ve parlamenter yapısıyla dikkat çekiyordu. Yeni siyasi yapının liberal özelliğinden dolayı bir taraftan devlet küçülürken bir taraftan da sivil toplum örgütlerinin sayısı çoğalmaya başlamıştı. Bununla birlikte kültürel/sanatsal faaliyetlerin artmasına karşın, ekonomi oldukça zayıflamıştı ve işsizlik oranı da yüksek seviyelere çıkmıştı. Böylesi bir durumu iyi bir propaganda malzemesi haline getiren Hitler'in partisi NSDAP ise herkesin işinin olacağı müreffeh bir toplumsal yapı vaat ederek popülerliğini artırıyordu (Graf 2008: 364). Weimar Almanyası ekonomik kriz ve işsizliğin yanında uluslararası arenada Büyük Britanya ve ABD’nin hegemonyasında/gölgesinde pasif bir ülke olmaktan kurtulamamıştı.

Schmitt ise söz konusu ülkelerin hegemonyasındaki küreselleşmeye karş1 çıkarak içte ekonomik krizin ve dışta ise pasifleşmenin temel nedeninin ülkesinde uygulanan parlamenter demokrasi olduğu kanaatindedir (Ottmann 1993: 198). Söz konusu liberal sistem, devlet merkezli bir anlayışın aksine halka doğru açılarak sivil toplum kuruluşlarının ve sendikaların artmasını teşvik ediyordu. Schmitt'e göre ülkesinde parlamenter demokrasi ve liberal sistem ülkeyi içte ve dışta ekonomik olarak buhrana sürüklemektedir. Onun NSDAP ile yakınlaşmasının temel nedeni mezkûr parlamenter/liberal yapıya olan muhalif tutumudur, zira her iki cenahta bu yapıya karşı tavır almışlardı. Schmitt'e göre öncelikle devlet etrafında birleşmiş ulusal bir bilincin oluşması gerekmektedir (Çelebi 2014: 13). Onun Büyük Britanya ve ABD’nin 
hegemonyasına karşı ulusal bir bilinç oluşturma gayesi, dönemin şartları bağlamında irdelendiğinde belki de makul bir yöntem olarak nitelenebilir. Ancak sonraları Hitler iktidarının yol açtığı işgaller, soykırım ve II. Dünya Savaşı, onun fikirlerinin de mütemadiyen bu bağlam içinde irdelenmesine neden olacaktır.

Schmitt, ülkesinin içinde bulunduğu söz konusu hegemonya/kuşatılmışlık durumuna karşın entelektüel bir mücadele vermeyi bir görev olarak addetmektedir. Ona göre tarihte ülkesinin içinde bulunduğu kriz ve tehlike durumlarında kalemiyle mücadele veren birçok düşünür mevcuttur. Sözgelimi Machiavelli 16. yüzyılda ülkesi İtalya'yı; Alman, Fransız, İspanyol ve Türk istilasına karşı Prens adlı bir eser yazarak örnek bir mücadele vermiştir. Benzer bir entelektüel savunma biçimini Almanya için Fichte ve Hegel 19. yüzyıl başında, Napolyon'un (Fransa'nın) istilasına karşı sergilemişlerdir (Schmitt 2014b: 96). Ülkesinin içinde olduğu pasif durumun temel nedeni Schmitt'e göre parlamenter demokrasi anlayışının bir sonucu olarak devletin merkezi otoritesinin zayıflayarak (ya da zayıflatılarak) topluma doğru genişlemesi ve sivil toplum örgütlenmelerinin güçlenmesidir. İçte ve diştaki söz konusu atıl ve tayin edici $^{1}$ olamama durumu ona göre devletin meşruiyetini ciddi anlamda sorgulamayı gerektirmektedir. $\mathrm{Bu}$ çerçevede Schmitt, mevcut yönetim sisteminin değişmesini öngörerek bir taraftan devrimci bir tavır içinde olurken diğer taraftan güçlü bir lider etrafında ulus bilinciyle birleşmiş bir Almanya önerdiği için muhafazakâr bir tutum içindedir. Öyle ki ülkenin içinde bulunduğu pasiflik ve kuşatılmışlık durumu onu hem devrimci hem de muhafazakâr fikirleri sentezleyen bir düşünür olma durumunda birakmıştır.

Schmitt'in ülkenin içinde bulunduğu durum için temel sorun olarak gördüğü çoğulcu yönetim anlayışına karşı önerdiği güçlü merkezi otorite yönündeki fikirleri zamanla daha sistematik bir hal alacaktır. Çünkü Weimar Almanyasının ekonomik kriz içinde bulunmasının ve dış ilişkilerde karar verebilme yetkisini kaybederek pasif bir

\footnotetext{
${ }^{1}$ Tayin edicilik, diğer bir ifadeyle karar vericilik (Dezisionismus) Schmitt'in Hobbes'tan mülhem formüle ettiği bir kavramdır. Buna göre devleti devlet yapan temel özellik, zor ve olağandışı durumlarda karar verebilme mekanizmasını mutlak anlamda elinde bulundurmasıdır. Bkz. SCHMITT, Carl (2016). Siyasi İlahiyat, çev. A. Emre Zeybekoğlu, Ankara: Dost Kitabevi Yayınları.
} 
ülke olmasının temel nedeni liberal parlamenter sistemle yönetiliyor olmasıdır (Schmitt 2014a: 37-38). Bu çerçevede onun devletin yapısıyla ilgili düşüncelerinin Hobbes’tan mülhem bir telakkide şekillendiği oldukça belirgindir. Çoğulcu liberal anlayışın bir yansıması olarak siyasi olmayan sendikalar ve derneklerin sayısı oldukça artamaya başlamıştı. Bunun üzerine Schmitt'in ulus karakterli güçlü bir devlet anlayışına sarılması aynı zamanda devletin çoğulcu teorilerle küçülüp halka doğru yayıldığı ve sivil toplum yapılanmalarının yaygınlaştığı mevcut yapıya karşı meydan okumadır (Herasuforderung) (Schmitt 2014b: 42). O, 1927 yılında ilk kez yayınlanan Siyasal Kavramı adlı eseri ile temel amacının Almanya'nın içinde bulunduğu pasif duruma dikkat çekmek olduğunu ifade eder (Çelebi 2014: 16). Şu halde, söz konusu atıl sistem ivedilikle terk edilerek siyasi otoritenin güçlü bir liderin elinde olduğu bir yapının oluşması gerekmektedir. Bu değişimin sağlanması ve siyasi birliğin sağlam bir şekilde oluşması için Alman halkının kendi ulusal kimliğinin farkına varması gerekmektedir. Schmitt, söz konusu siyaset felsefesini kurgularken titiz bir filozof edasıyla işe siyaset antropolojisi analizleriyle başlar. İkinci adımda ise söz konusu tahlillerden hareketle mevcut duruma ilişkin siyaset felsefesini şekillendirmeye çalışır.

\section{Schmitt'in Siyasi Antropolojisi ve Referansları}

Schmitt'in çoğulcu teorilere ve liberalizme yönelttiği eleştiriyi serimleyebilmek için öncelikle onun siyaset antropolojisini nasıl kurguladığına göz atmak gerekmektedir. Çünkü onun temellendirmelerinde siyasi antropolojinin kavram ve argümanları önemli bir yer tutmaktadır. Schmitt, kendisi gibi Alman olan ve toplumlar arasında oluşması muhtemel bir ebedi barış (Yeşilçayır 2017: 128-142) düşüncesinden söz eden Kant'ın aksine adeta ebedi savaşın hüküm sürdüğü bir anlayış içindedir. Zira herkesin barış, güven ve huzur içinde yaşadığı bir dünyada kötülük de olmayacağından papaz, teolog, hukukçu ve ahlakçı da olmayacaktı. Ancak dün olduğu gibi bugün de yeryüzünde kötülüğün, savaşın ve kargaşanın eksik olmadığg şüphe götürmez bir gerçektir (Schmitt 2014b: 95). Şu halde Schmitt, yeryüzünde mütemadiyen var olan kötülügün insan doğasında var olduğu kanaatindedir ve düşünce tarihinde bu teoriyi önemseyen 
filozofların fikirleri oldukça muteberdir. Onun için söz konusu filozofların en önde geleni Hobbes'tur, çünkü Hobbes, insan doğasındaki kötülük fikrinden hareketle etkili bir siyaset felsefesi kaleme almıştır.

Schmitt'e göre Hobbes'un insan doğasına dair belirlediği kötümser tutumu ve herkesin herkese karşı savaş içinde olduğu savı yaşadığı dönem itibariyle daha anlaşılır bir fikir olarak yansımaktadır. Bu noktada Hobbes'un insan antropolojisi hakkındaki düşüncesinden söz etmek yerinde bir tutum olacaktır. $O$, insanların doğuştan eşit olduğunu savunarak bu eşitlikten güvensizlik doğduğunu iddia eder. Şu halde iki kişi aynı anda bir şeye sahip olmak isterlerse birbirlerine düşman olurlar; bu nedenle birbirlerini yok etmeye ve egemenlik altına almaya çalışırlar. Bununla birlikte insan doğasında rekabet, güvensizlik ve şöhret olmak üzere üç temel kavga nedeni mevcuttur (Hobbes 2008: 93-94). İnsan doğasının mezkûr mahiyetinden dolayı onu, her an kötüye meyletme ihtimali olan bir varlık olarak nitelendirmek yerinde bir tutum olacaktır. Ancak toplum hayatının huzurlu ve güvenli olabilmesi için insanın söz konusu riskli tarafı göz önünde tutularak buna göre önlemlerin alınması gerekir. Hobbes'un söz konusu problem için önerisi, toplumu/ülkeyi tanrısal yetkilerle donatılmış mutlak bir liderin yönetmesi yönündedir. Onun Leviathan adını verdiği lider, herkesin iradesini teslim ettiği ve kendisinden korku duyulan bir kraldır. Dolayısıyla Hobbes için güvensiz ve kötüye temayül etme riski bulunan insanoğlu için en etkili siyasi anlayış, egemenliğin mutlak ve tek elde toplandığı monarşi sistemidir. Devlet halinde yaşarken insanları özgürlükleri konusunda kısıtlamanın nedeni, kendilerini korumak ve böylece daha mutlu bir hayat sürmektir. İnsanları ceza tehdidiyle ve korku içinde tutacak bir güç olmadığı (Leviathan) müddetçe savaş soğuk yüzünü sürekli gösterecektir (Hobbes 2008: 127).

Buna uygun olarak Hobbes, çoğulcu ve demokratik anlayışlara karşı mesafelidir, çünkü mutlak egemenin gücünü sınırlandıracak anlayışlar, düzensizlik ve çatışmaya zemin hazırlayacaktır. Halkın yönetimde söz sahibi olabileceği demokrasi türü yönetimler kulağa hoş gelebilir, hatta iyi de olabilir ancak insanlardan oluşan bir toplumu yönetmek için oldukça verimsiz bir güç türüdür (Hobbes 1998: XV-XXXVI). 
Bu noktada Hobbes'un iç savaşlarla boğuşan bir İngiltere'de yaşadığı ve söz konusu şartların fikirlerini kaleme alırken etkili olduğu göz önünde tutulmalıdır. Netice olarak Hobbes'a göre demokratik yönetim anlayışı her ne kadar kulağa hoş gelse de toplumu sağlıklı bir şekilde yönetebilmek için verimsiz bir sistemdir. Schmitt'in temel eserlerini kaleme aldığı döneme I. Dünya Savaşı damgasını vurmuştu ve ülkesi bu savaştan en çok etkilenen ülkelerden biriydi. Yukarıda belirttiğimiz gibi Almanya siyasi anlamda içte ve dişta pasif bir durumdayd. Böylesi bir durumda Schmitt'in Hobbes'un düşüncelerine itibar etmesi mantıklı bir temel üzerine oturmaktadır. O, ülkesinin içinde bulunduğu ekonomik ve siyasi darboğazdan ancak güçlü bir lider sayesinde çıkabileceğine inanarak güçlü merkezi otorite sistemi için Hobbes’u ve onun mutlak monarşi anlayışını örnek alır.

Kervegan'a göre Schmitt'in hukuk ve siyasetle ilgili düşüncelerinin temelini Hobbes'un "Yasayı yapan hakikat değil, otoritedir (Autotitas, non veritas facit legem)." ilkesi belirlemiştir (Kervegan 1988: 372). Öyle ki Hobbes, egemen güç ve hukuk yasaları arasındaki ilişkinin nasıl olması gerektiğini serimlerken Leviathan'ın kendi yaptığı yasaların altında kalmasının anlamsız olacağını ifade ediyordu. Buna göre, egemen gücün toplum yasalarına tabi kılınması devletin doğasına aykırıdır, çünkü egemenin/liderin kendi yaptığg yasaların üstünde olması gerekir. Yasaları egemenin üzerine koymak yeni bir egemen yaratmak anlamına geleceğinden büyük bir yanılg1 olacaktır (Hobbes 2008: 228). Hobbes'a benzer şekilde Schmitt, hukukun büyük bir siyasal kararın gölgesinde, yani istikrarlı bir devlet içinde bir anlam ifade ettiğini savunmaktadır. Hukukun üstünlügünü savunanlar siyasi erkin yanında başka bir gücün meşrulaşmasını savunanlardır. Ona göre Hobbes, herkesten çok daha açık bir biçimde siyasal yapının nasıl olması gerektiğini şüpheye yer bırakmayacak şekilde dile getirmiştir. Buna göre hukukun egemenliği demek, hukuk normlarını koyanların egemenliği anlamına gelecektir (Schmitt 2014b: 97). Bu noktada Schmitt normatif ve evrensel hukuk teorisyenleri Kant ve onun yolundan giden Hans Kelsen gibi isimleri eleştirir (Schmitt 2016: 30). Dolayısıyla hukuk kuralları içeriğini mevcut siyasi otoriteden başka bir yerden alamaz. Eğer bu ilke, ülke yönetiminde benimsenirse temsil 
ve karar verebilme mekanizması sadece merkezi otoritenin elinde olacaktır ve çoğulcu/parlamenter sistemin neden olduğu başıbozukluk durumu ortadan kalkacaktır.

Friedrich Balke'ye göre Schmitt, yeni bir siyaset antropolojisi ortaya atmaktan ziyade, mevcut duruma istinaden Hobbes ve onun gibi düşünenlerin antropolojisine olan inancı bir nevi yinelemiştir (Balke 1990: 38). Her ne kadar onun siyasi antropoloji konusundaki fikirleri Hobbes'tan referans alınarak kaleme alınmış olsa da devrinde ortaya çıkan gelişmeler neticesinde siyasetin asıl anlamından uzaklaştığı ile ilgili tezleri ve bu bağlamda ortaya attığı fikirler oldukça özgündür. Öyle ki Schmitt, insanın hayatını belirleyen temel ilke olduğundan siyaseti, insanın kaderi olarak nitelendirir (Schmitt 2014b: 108). Ancak liberal ideolojinin yol açtı̆̆ ekonomi teorisi siyaseti zayıflatarak özüne yabancılaştırmaktadır. Onun bu anlayışlara karşı yönelttiği eleştirilere gelecek bölümde tekrar döneceğiz. Schmitt'in siyaset felsefesini kaleme alırken en az Hobbes kadar referans aldığı diğer bir filozof ise şüphesiz Hegel'dir.

Hegel'in siyaset felsefesi için birey-devlet ilişkisini ele alış tarzı ve bu minvalde ortaya attığ1 argümanlar özgün bir karaktere sahiptir. O, Hukuk Felsefesinin Prensipleri adlı eserinde birey-devlet ilişkisinin nasıl olması gerektiğini ortaya koyar. Burada en dikkat çekici husus şüphesiz Hegel'in Yeniçağ'da, -Hobbes, Locke, Rousseau ve Kant vasıtasıyla- etkisini iyice hissettiren sözleşmeci kuramların aksine farklı temellendirmeler ortaya atmasıdır (Topakkaya 2006: 192). Buna göre devleti oluşturan birey değildir, devlet, özel kendilik bilinci içinde kendiliğinde ve kendisi için rasyoneldir. Eğer devlet, sivil toplum örgütleriyle karıştırılırsa ya da özgürlüğü koruyan bir kurum olarak algilanırsa üyesi olunan ihtiyari bir yapı olmak durumunda kalır (Hegel 2004: 199). Şu halde Hegel'in sözleşmeci kuramlardan farklı bir anlayış benimsemekle birlikte liberal söylemlere de eleştirisi açıç̧a hissedilmektedir. O, devletin sadece bireylerin koruma görevine hizmet eden kurum olduğunu savunan bir anlama biçimini reddeder. Bunun yanında devleti, sadece bireyin bireyselliğini tatmin etme aracı olarak görmek abesle iştigal etmektir (Bayar Bravo 2006: 112). Schmitt için bu düşünceler, özellikle yaşadığı dönemin şartları düşünüldüğünde oldukça isabetli ve tutarlıdır. Öyle ki o, liberal anlayışın bir yansıması olarak ülkesinde merkezi devlet 
otoritesinin zayıflayarak sivil toplum örgütleri ve sendikaların hızlı bir şekilde çoğalmasından oldukça kaygı duyuyordu.

Hegel'e göre bireyin devletle ilişkisi sözleşmeci ve liberal anlayışlardan başkadır, buna göre birey ancak devletin üyesi olmakla hakiki birey olabilir. Çünkü devlet kendiliğinde rasyonel şeydir, onun birey tarafından bilinip bilinmemesi ya da kabul edilip edilmemesi bir şeyi değiştirmez (Hegel 2004: 200-201). Görebildiğimiz kadarıyla birey devleti oluşturan bir unsur olmaktan ziyade, devlet bireyi oluşturmaktadır. Diğer bir ifadeyle alt yapı üst yapıyı değil, üst yapı alt yapıyı meydana getirmektedir (Topakkaya 2008: 386). Hegel, devlet-toplum ilişkisine yönelik yaklaşımını sürdürerek aile ve sivil toplumu da devlete nazaran ikincil konumlar olarak nitelendirir. Buna göre birey, aile ve toplum bir anlamda devlet içindir ve devlet gerektiğinde söz konusu ikincil konumlardan çeşitli fedakârlıklar talep edebilir (Hegel 2004: 204). Bunun diğer izahı şudur: Devlet, halkına olağan durumda sunduğu hizmetin, sağladığı imkânların karşılığını olağanüstü durumlarda talep edebilir. Bu nokta Schmitt'te büyük oranda karşılık bulur, öyle ki olağanüstü durumda devletin tayin edicilik/karar vericilik iradesini mutlak anlamda elinde bulundurması oldukça önemlidir. ${ }^{2}$ Hegel için devleti oluşturan temel ilke, gücünü onun tarih ve kültüründen alan cevhersel varlığıdır ve bu cevhersellik devletin dünyaya kök salmış ruhu olarak onun subjektif tarafını belirler (Hegel 2004: 212). Dolayısıyla devletin kendisi için siyasi yapı olması özelliğini burada sözü edilen subjektiflik bağlamında düşünmek gerekmektedir. Devleti diğer devletlerden ayıran temel unsur olan subjektifliği belirleyen ise toplumların öznel tarih ve kültüre sahip olmalarıdır. Onun bu tutumu, Schmitt'te ulus bilinci etrafında birleşmiş bir Almanya ideali şeklinde tezahür edecektir.

Hegel'e göre sözleşmeci kuramı savunanların iddia ettiği gibi, devleti bireyin özgür tercihiyle katıldığı bir kurum olarak düşünmek doğru bir tutum değildir. Çünkü devlet, tümelin nesnel olarak cisimleşmiş halidir ve insanlığın en derin özünü ve

\footnotetext{
2 Almanca'da Ausnahmezustand olarak ifade edilen söz konusu olağandışı durum Schmitt'e göre siyaseti belirleyen temel unsurlardan biridir. Böylesi durumlarda devlet mutlak karar verici bir otorite olarak erki elinde tutmalıdır. Örneğin, olağanüstü bir durumda savaşa karar verme mekanizması, ne dış güçlere ne de yurttaşlara danışmadan mutlak olarak devletin kendi iradesinde olmalıdır.
} 
yazgısını temsil eder. Buna göre devlet insana nesnelliğini ve özünü kazandıran nesnel bir yapıdır. Şu halde devleti, bireyle yapılan bir sözleşme temeli üzerine kurulmuş bir yapı olarak değil, onun yazgısal olarak katılıp birey olabileceği nesnel bir yapı olarak düşünmek gerekir (Bayar Bravo 2006: 112-113). Aslında Schmitt'in siyasetin insanın kaderi olduğunun altını çizmesi (Schmitt 2014b: 108) bu anlayışa oldukça yakın durmaktadır. Bu nokta aynı zamanda onun liberal anlayışı eleştirirken başvurduğu temel argümanlardan biri olarak dikkat çekmektedir, çünkü devlet bireylerin özgür kararlarıyla katıldıkları bir kurum değildir, bilakis bireyin üyesi olarak ulusal ve kültürel aidiyet duygusunu kazandığı yapıdır.

Hegel'in Schmitt üzerinde etkili olan siyasi düşünceleri şüphesiz bunlarla sınırlı değildir. Sözgelimi onun kuvvetler ayrılığının devleti zayıflatmaya ve parçalanmaya sürükleyeceğinden söz etmesi önemli bir ilke olarak karşımıza çıkar. Devlet, kendisi için siyasal bir yapıdır, güçler ayrılığı sağlıksız bir düşüncedir, çünkü Hegel için devlet parçalanamaz bütün bir cevherdir (Hegel 2004: 222). Bu bağlamda yine onun liberal ve çoğulcu teorilere olan itirazı yer almaktadır. Buraya kadar anlatılanlardan Schmitt'in siyasi düşüncelerinin oluşumunda felsefe tarihinden temel referans kaynaklarının Hobbes ve Hegel olduğu anlaşılmaktadır. Bu temel belirlemelerden sonra onun çoğulcu siyasi rejimlere ve liberalizme karşı tutumunu tahlil etmek yerinde olacaktır.

\section{Schmitt'in Liberalizm Eleştirisi}

Schmitt'in çoğulcu/liberal siyasi anlayışlara yönelttiği eleştirileri, yukarıda değinmeye çalıştığımız düşünceler zemininde şekillenir. Ona göre liberal parlamenter sistemle yönetilmeye çalışılan ülkesi Weimar Cumhuriyetinde siyaset kurumu temel fonksiyonu önemli ölçüde kaybetmiştir. $\mathrm{Bu}$ ülkenin içinde bulunduğu sorunlara yukarıda değinmeye çalıştık. Bununla birlikte Schmitt'e göre çoğulcu/liberal anlayışın yol açtığı sorunları ve çözüm önerilerini şöyle sıralayabiliriz: Ona göre parlamenter demokratik sistemin siyasetin özüne verdiği zarar geçen yüzyılda fazla dikkat çekmemiştir, çünkü parlamentarizm demokrasiyle aynı anda ve çok yakın bir işbirliği 
içinde gelişim gösterdiği için bu ikisi arasında açık bir ayrım yapılmamıştır. Ancak gelinen noktada liberal-parlamentarizm fikrinin kitle demokrasisi ile harmanlandığ görülmektedir (Schmitt 2014a: 17). Onun temel amacı ise söz konusu ayrımı yapabilmek için entelektüel anlamda kavram ve fikir üretmektir, böylelikle özüne yabancılaştırıldığını düşündüğü siyaset anlayışına/kavramına asıl muhtevasını tekrar kazandirmak gerekmektedir. Bununla birlikte Schmitt'in temel olarak hedefinde olan fikirler arasında bir ayrım yapmak gerekir; çünkü o, özü itibariyle demokrasi ile bir mücadele içinde değildir. Ancak demokrasinin değişik ideolojiler vasıtasıyla dönüşüp farklı amaçlar için kullanılmasına karşı bir tutum sergiler. Temel olarak liberal teorinin bir yansıması olarak parlamenter demokrasi anlayışını eleştirir. Ona göre söz konusu çelişkileri içinde barındırdığı için parlamenter demokrasi anlayışındaki parlamento ve demokrasi kurumları/kavramlarının birbirinden ayrıştırılması gerekmektedir. Çünkü o, parlamentarizm ve demokrasinin aslında çok fazla örtüşen kavramlar olmadığ1 kanaatindedir. Parlamentarizm düşüncesi oldukça demokrat bir düşünce gibi görünür ancak eğer pratik ve teknik sebeplerle halk adına temsilcileri de karar verebiliyorsa aynı halk adına tek bir temsilci de karar verebilir. Bu gerekçelendirme demokratik olmaktan çıkmaksızın anti-parlamenter bir diktatörlüğü de haklı çıkarabilir (Schmitt 2014a: 52). Bu noktada Schmitt, parlamenter ve liberal teorileri ülke yönetimindeki durumunu ve böylesi bir durumda iktidarın hangi ölçüde muktedir olduğunu sorgular.

Schmitt'e göre parlamenter sistemde devlete ait işlerin hükûmeti yöneten parti üyelerine ve taraftarlarına sunulduğu açık bir şekilde görülmektedir. Böylelikle parlamenter sistemde partiler adeta ticari ve ekonomik anlamda bir kazanç kapısı olarak algılanmaya başlanmıştır. O, Parlamenter Demokrasinin Krizi'nde bu konuyu detaylı olarak ele alarak partilerin ülkenin geneline hizmet götürmek yerine yandaşlarına birtakım mal ve ihaleleri peşkeş çekmelerinin siyasetin özüne zarar veren faktörlerden biri olduğuna dikkat çekmek ister. Çünkü siyasi olduğunu iddia eden partiler müzakerelerinde, sürekli olarak çıkarlarını ve iktidar şansını yükseltmenin planlarını yapmaktadırlar. Gelinen noktada rakibi neyin gerçek ve adil olduğu hususunda ikna edebilmek değil, hükmedebilmek için çoğunluğu elde etmenin yollarını bulmaktır 
(Schmitt 2014a: 19-22). Ona göre uygulanmaya çalışılan parlamenter demokraside yalnızca eşitlerin eşitliği ve eşitler safında yer alanların iradesi söz konusu olmaya başlamıştır. Ancak bu durumda demokrasinin bir gizli oy kayıt sisteminden farklı bir şey olduğu açıkça görülmektedir. O halde demokratik ilkeleri kullanarak zımnen diktatörce bir yönetim anlayışı uygulamak bile mümkün hale gelebilir (Schmitt 2014a: 34-35). Bununla birlikte parlamenter demokrasi azınlığın iradesini çoğunluğa tabi kıldığından buradaki eşitlik anlayışının tartışmalı bir konu olduğu ortaya çıkmaktadır. Dolayısıyla Schmitt için halk iradesi kuramının kadim diyalektiği aydınlatılmış bir durum değildir, çünkü propaganda ve kamuoyu manipülasyonu yoluyla halkın aldatılabilir olduğu uzun süredir bilinmektedir (Schmitt 2014a: 42-43).

Schmitt'in kaleme aldığı mezkûr düşünceler sanki Almanya'da 1933-1944 döneminde ortaya çıkacak bazı gelişmeleri önceden seziyor izlenimi uyandırmaktadır. Çünkü onun parlamenter sistemde halkın oy potansiyelinin partiler tarafindan manipüle edilmeye müsait bir yapısının olduğunu iddia etmesi, sonraları yoğun bir şekilde karşılaşılan durum olmuştur. Hitler'in herkesin işinin olduğu, zengin ve refah bir ülke vaatleriyle halkın oy potansiyelini önemli ölçüde manipüle etmesi tarihî anlamda inkâr edilemez bir gerçektir. Bu noktayı aslında Schmitt'e yönelik bir eleştiri olarak belirlemek yanlış olmasa gerekir. Çünkü onun, halk oylamalarının manipüle edilebilir olduğuna dikkat çekmesi, bir dönem üyesi olduğu ve ortak fikirleri olan NSDAP tarafından ileriki dönemlerde fazlasıyla kullanılmaya başlanmıştır. O, parlamenter demokrasi ile ilgili tespitlerinde, propaganda ve eğitim yoluyla iktidarın kendi ideolojisini halka kabul ettirebileceği hususuna dikkat çeker. $\mathrm{Bu}$ anlayışa göre demokrasinin diktatörlüğün zıddı olmadığı durumlarda vakidir. Bir diktatörün hâkim olduğu böylesi bir geçiş sürecinde dahi demokratik özdeşlik hüküm sürebilir ve halk iradesi diktatörü kendisi belirleyebilir (Schmitt 2014a: 45). Bu noktada yine Hitler yönetimindeki Almanya'nın ne kadar demokratik ve ne kadar da diktatörlükle iç içe olduğunun en güzel örneklerinden birini sunmuştur. Kaderin bir cilvesi olarak Schmitt'in öne sürdüğü fikirler adeta sonraları kendi ülkesinin başına gelmiştir. 
O, Siyasal Kavramı'nda devletin mutlak güç merkezi olmasını reddeden çoğulcu/liberal teorilerin yalnızca devletin dağılmasının ya da olumsuzlanmasının teorisi olabileceğini iddia eder, çünkü bu teorilerde devlet, âdeta devlet içinde kurulmasına müsaade edilmiş sivil toplum kuruluşları ve sendikalarla rekabete girişen basit bir örgüte dönüşür (Schmitt 2014b: 73). Schmitt, bu noktada çoğulcu bir anlayışla yönetilen ülkede siyasal birlikten söz etmek mümkün müdür sorusunun cevabını bulmaya çalışır. Ona göre liberal ve çoğulcu siyasi teorilerde devlet, içindeki örgütlenmelere federatif bir statü kazandıkları için oldukça tehlikeli yapılanmalardır. Çünkü söz konusu dinsel, ekonomik ve sendikal örgütlenmeler, devletin kontrolünden çıkarak adeta devlet içinde otonom birer devletçik haline gelmişlerdir (Schmitt 2014b: 73). Bunun yanında Schmitt, merkezi otoritenin zayıflayarak halka doğru yayılmasının başka bir tehlikenin daha kapısını araladığına dikkat çeker. Şu halde sivil toplum kuruluşu olarak ortaya çıkan örgütlerin gerçek hedeflerinden devlet çoğu kez haberdar değildir. Merkezi siyasi otoritenin zayıflaması ve iktidarın halka doğru yayılması ile birlikte faaliyetlerini gizlilikle yürüten birçok otonom yapının oluşması kaçınılmazdır. Netice itibariyle o, çoğulcu ve liberal siyasi rejimlerin aynı zamanda devletin parçalanması ve sona ermesine yol açan fikirler olduğu kanaatindedir.

Schmitt, mezkûr sorunların temelinde liberalizm ve onun popüler hale getirdiği iktisadi sistemin olduğunu ifade eder. Çünkü anarşist bir teori olmadıkları halde liberal teoriler, devletin sosyal ve ekonomik ilişkilere müdahalesine karşıdırlar. Onlar için insanın ve toplumun iyiliği, devletin toplumun hizmetine yönelik çalışmalar yapan bir kuruma dönüşmesine bağlıdır. Diğer bir ifadeyle toplumun düzenini kendi içinde bulabilmesi için devletin sınırlı olduğu alanın dışına çıkmaması gerekmektedir. Schmitt'e göre devletin sınırlanması ve denetlenmesini öngören söz konusu liberal anlayışı, bir devlet teorisi olarak nitelendirmekten ziyade, devleti yok etme teorisi olarak adlandırılmak daha tutarlı bir yaklaşım olacaktır (Schmitt 2014b: 91). Çünkü tarihsel bir gerçeklik olarak liberalizme bakıldığında siyasal kavramını/kurumunu kendine has ve sistematik bir biçimde dönüştürdüğünü ve özüne yabancı bir yapı haline getirdiği görülmektedir (Schmitt 2014b: 100). Buna göre liberal bir siyaset 
telakkisinden ziyade, siyasetin liberal eleştirisi ile karşı karşıya kalındığını ifade etmek gerekir. Şu halde siyaset, liberal anlayışla birlikte değişmiş ve özüne yabancılaşmış bir kavram/kurum olmak durumunda kalmıştır. Bunun en bariz göstergesi ise liberalizmin bireysel özgürlüklerin ve özel mülkiyetin korunması için devleti sınırları belli bir güvenlik birimi haline dönüştürmesidir (Schmitt 2014b: 101). O, bu noktada, acaba bu teoriler insana ve hayata dair her şeyi doğru bir biçimde mi uygulamaktadırlar diye bir soru yönelterek liberal teorilerin yol açtığg sorunları irdelemek ister.

Schmitt, bu soruya yönelik analizinde geçen bölümde değinmeye çalıştı̆̆ımız siyasi antropolojiden hareket eder. Şu halde o, insanın kötüye temayül edebilecek yönünün sürekli mevcut olduğuna inanarak insanı risk grubunda bir varlık olarak değerlendiriyordu. Yeryüzünden savaşların hiç eksik olmaması bu teoriyi kanıtlar mahiyettedir. Schmitt, bu bağlamda liberallerin söz konusu gerçekliği anlamaktan oldukça uzak olduklarına dikkat çekmek için savaştan söz eder, zira Hobbes, bu gerçeğin farkına iç savaşın en kötü zamanlarında varmıştır. Öyle ki insanların tasasız ve güvenli dönemlerinde siyasi gerçeklik konusunda kendilerini inandırdıkları meşruiyet fikri, savaş dönemlerinde tamamen değişmektedir (Schmitt 2014b: 82). Schmitt'e göre savaş dönemleri, olağandışı durumlardır ve aslında bu dönemler insanın hayatın gerçeklerini görebilmesi için sıradan durumdan daha önemli bir yere sahiptir (Schmitt 2016: 22). Hiçbir dert ve sorunun olmadığı zamanlarda insanlar gerçekten de liberal ve çoğulcu teorilerin önerdiği devletin bireysel özgürlükler için sınırlanması gerektiği fikrine değer verebilirler. Ancak savaş ve kargaşa durumlarında sivil toplum kuruluşları ve diğer örgütlenmeler, yurttaşlara devletin sağladığg güveni verebilirler mi? Ya da onları muhtemel saldırılara karşı koruyabilir mi? Schmitt'e göre devletin küçülerek halka ve sivil topluma doğru açılmasını savunan liberal/çoğulcu teoriyi savunanların cevabını vermesi gereken temel soru budur.

Dolayısıyla olağandışı durumlar, insanın kötü özelliğinin mutlak suretiyle kendini belli ettiği dönemlerdir. Böyle zamanlarda insanın hissettiği acizlik ve korunma hissiyatı devletin önemini belirgin bir şekilde ortaya çıkarır. Schmitt'e göre devletin yurttaşlarını sağlıklı bir biçimde koruması onların mevcut yönetime mutlak itaatiyle 
ilintili bir durumdur. Ona göre koruma-itaat aksiyomunun asli doğruluğu özellikle diş politikada, devletlerin kendi aralarındaki ilişkilerde ortaya çıkar. Hegemonya ve manda rejimlerine bakılarak devletin siyasi otoritesinin mutlak ve güçlü olması gerektiği iyi anlaş1labilir (Schmitt 2014b: 82). Schmitt, Hobbes'un insan insanın kurdudur sözünün siyasete yansımış halini şu ifade ile anlatmaya çalışır: "Savunmasız bir halkın sadece dostları olduğunu düşünmek safdillik olacağı gibi, düşmanın, bir halkın direnmemesinden olumlu anlamda etkileneceğini ummak da aptalca olurdu" (Schmitt 2014b: 83; Topakkaya 2007: 5). Dolayısıyla onun siyaset kaderimizdir sözü bu bağlamda daha anlaşılır bir hale dönüşmektedir. Şu halde siyaset olmadan dünyanın ahlaki, hukuki ve ekonomik anlamda iyileşeceğini ummak beyhude bir çabadır. Schmitt'e göre liberal teoriler, siyasetin özündeki birlik ve mutlak karar verici olma özelliklerini bozma temayülleri içindedirler. Oysa siyaset bir devlete gücü veren asli kurumdur, böylelikle yurttaşlarını dış güçlere karşı gerekli önlemleri alarak onları düşmanlardan ve kötülüklerden koruma yetkisini sunar. Liberalizm ise tam tersi bir anlayışla bu gücü baltalar ve merkezi siyasi iradenin zayıflamasına neden olur. Bununla birlikte zayıf bir halkın ortadan kalkması kaçınılmazdır, çünkü tarih bunun örnekleriyle doludur.

Schmitt, çoğulcu ve liberal teori eleştirisini diğer bir üstadı olan Hegel'den alıntıladığı fikirlerle sürdürür. Geçen bölümde Hegel'in devletin parçalanamaz bütün cevher olduğunu ve kuvvetler ayrılığının devletin zayıflamasına ve parçalanmasına neden olacağını savunduğundan söz ettik. Schmitt, devrinde yaygınlaşmaya başlayan liberal anlayışlara karşı devlet erkinin parçalamaz bir cevher olduğu anlayışına sımsıkı bağlanır. Devletin cevhersel bir birlik olması, devlet ve halkın sıkı bir birlik olduğu anlamına gelir ki sivil toplum ve diğer örgütler bu bağı zayıflatacaktır. Liberalizmin önerdiği söz konusu anlayış devleti topluma dönüştürerek zayıflatacaktır. Şu halde liberallerin iddia ettikleri gibi yurttaşları siyasetten ayrı tutmak doğru bir tutum değildir, çünkü siyaset insan hayatıyla minimal değil, kolektif olarak ilgilidir (Balke 1990: 4142). Bu noktada Hegel'in birey-devlet ilişkisi bağlamında ortaya attığı temellendirmeye atıfta bulunur. Liberal cenahın iddia ettiği bireyin devleti meydana getirdiği anlayışı 
safsatadır, çünkü birey ancak devlet yoluyla birey olur ve kendini devlette bulur. Devlet, mutlak güç merkezi olarak bireyi ve aileyi kurgulayan bir yapıdır. Schmitt, onun bu düşüncelerini kolektif millileşmeye dayalı yeni bir Almanya yaratma ideali doğrultusunda yorumlayacaktır. Gücünü tarih ve kültüründen alan bu yeni ülke, güçlü bir lider tarafından yönetilecek ve yurttaşlar kimliklerini bu ülkede bulacaklardır. Ancak böylelikle içte ve dışta krizde olan siyasi ve ekonomik yapıdan kurtulmak mümkün olacaktır.

Schmitt, yaşadığı dönemde Yeniçağ’dan beri süregelen siyaset felsefesinin bir neticesi olarak siyaset kurumunun özüne yabancılaştığını iddia eder. Söz konusu özüne yabancılaşmada siyasetle ilgili olmayan birçok kurumun ortaya çıkmasının yanında siyasi otoritenin zayıflamasının da önemli bir rolü bulunmaktadır. Ona göre devrinde ortaya çıkan çoğulcu liberal teoriler, devlet gücünün zayıflamasının temel nedenidir ve Almanya söz konusu problemin yaşandığ en belirgin ülkelerin başında gelir. Söz konusu sorunların giderilmesi için öncelikle siyasetin karşısındaymış gibi sunulmaya çalışılan ekonomi, din, kültür, hukuk, bilim gibi alanların depolitizasyonu paradigmasının değişmesi gerekir (Schmitt 2014b: 54). Buna göre politik olmayan hiçbir şeyin varlığının kabul edilmemesi gerektiğini savunur; ekonomi, hukuk, kültür gibi ögelerin siyasetten bağımsız değil de siyasetin altında tasnif edilmesi gerekmektedir.

Görebildiğimiz kadarıyla Schmitt'in çoğulcu ve liberal teorileri eleştirirken temel olarak Hobbes ve Hegel'den referans almasının yanında felsefi anlamda eklektik olarak nitelendirebileceğimiz bir metodoloji benimsediği de gözden kaçmamaktadır. Şöyle ki o, Hobbes alımlamasında her ne kadar onun antropoloji, mutlak monarşi ve hukuk felsefesi gibi düşüncelerine başvursa da onun liberal fikirlerini ise ayıkladığı gözden kaçmamaktadır. Klasik liberalizmin ilk öncüleri aralarında gösterilen Hobbes’un söz gelimi "Devletin görevi bireysel güvenliktir." (Hobbes 2008: 127) anlayışının Schmitt'te bir karşılığı yoktur. Dolayısıyla onun eklektik/sentezci yöntemi kendi siyaset felsefesinin karakterine göre bir derleme yapmak suretinde ilerlemektedir. O, Leviathan 
yazarının kendi düşüncesine uygun fikirlerine başvurduktan sonra bunları Hegel'in siyaset felsefesiyle de harmanlamak suretiyle kendi felsefesini oluşturmaktadır.

\section{Sonuç Yerine}

Schmitt' in çoğulcu anlayışlara ve liberalizme yönelttiği eleştirileri analiz etmeye çalıştığımız bu çalışmada üç temel husus dikkat çekmektedir. Öncelikle Almanya'da nasyonal sosyalizmin yükselişe geçtiği bir dönemde yaşayan ve Hitler'in partisine belli bir dönem üye olduğu bilinen Schmitt'in entelektüel yönünün az bilindiği konusudur. Diğer bir ifadeyle onun felsefesi nasyonal sosyalizmin gölgesinde kalarak ya çok az tanınmış ya da Nazi merceği altında tahlil edilmek istenmiştir. Bunun yanında onun nasyonal sosyalizmin fikir babası olarak yaftalanmasını belki de talihsizlik olarak değerlendirmemiz mümkündür. Çünkü onun kaleme aldığı metinler oldukça derin felsefi ve entelektüel boyutu ile dikkat çekmektedir. Bunu ifade ederken bir taraftan da Schmitt' in bir dönem Hitler' in Partisi NSDAP olan yakınlaşmasının yadsınamayacağını da belirtmemiz gerekir.

Diğer taraftan çağında yükselişe geçip moda olan siyasi anlayışların cereyanına kendisini kaptırmayıp yaşanılan sorunların temelinde aslında popüler ideolojilerin olduğunu savunması onun özgünlüğünü ortaya koyan diğer bir husus olarak dikkat çekmektedir. Öyle ki siyaset kurumu, kadim anlayışından uzaklaştırılıp adeta özüne yabancılaştırılmıştır ve siyasi erk, başka kurumlara da özerklik tanınarak zayıflamıştır. Schmitt'in temel siyaset felsefesi, söz konusu sorunsalı iyi analiz edip sorunun çözümüne yönelik fikir ve kavramları üretmeye yöneliktir. Belki de onun eserlerine günümüzde artan ilginin nedeni söz konusu sorunsala ilişkin ortaya attığ özgün düşüncelerdir. $\mathrm{Bu}$ durum aynı zamanda uzun yıllar nasyonal sosyalizmin fikir babası olarak etiketlenen Schmitt'in filozof yönünün tanınıp anlaşılmaya başlandığına dair bir işarettir.

Son tahlilde ise onun liberal teorileri eleştirirken savaş olgusunu oldukça tutarlı bir argüman olarak kullanması dikkatlerden kaçmamaktadır. Şu halde, çoğulcu 
anlayışları ve liberal teoriyi savunan kişilerin, savaş durumunda nasıl bir tutum içinde olacakları sorusu oldukça ilginç bir yaklaşımdır. Schmitt'e göre savaş gibi olağandışı durumlar, devletin mutlak otoritesinin sürekli olarak güç merkezi kalması gerektiğine dair en etkili argümanı sunmaktadır. Bu erkin zayıflatılıp sivil toplum kuruluşlarına da özerklik verilmesi durumunda devletin zayıflaması söz konusu olacağından, içte zayıflayan siyasi irade ekonomik krize de neden olacağı gibi, uluslararası arenada ise pasifleşen bir ülke profili ortaya çıkacaktır. Netice olarak Schmitt'in siyaset felsefesi bağlamında liberal teorileri eleştirmesi, dönemin şartlarını iyi okumasının yanında bu alana kazandırdığı yeni kavram ve temellendirmeleri de içinde barındırmaktadır. 


\section{KAYNAKÇA}

BALKE, Friedrich (1990). "Zur politischen Anthropologie Carl Schmitts", Die Autonomie des Politischen, haz. Hans-Georg Flickinger, ss. 37-65, Weinheim: VCH Verlag.

BAYAR BRAVO, Işı1 (2006). "Hegel ve Liberalizm”, FLSF Dergisi, 2: 111121.

ÇELEBİ, Aykut (2014). "Sunuş", Carl Schmitt, Siyasal Kavramı, çev. Ece Göztepe, İstanbul: Metis Yayınları.

HEGEL, G. W. F. (2004). Hukuk Felsefesinin Prensipleri, çev. Cenap Karakaya, 2. Baskı, İstanbul: Sosyal Yayınları.

HOBBES, Thomas (2008). Leviathan, çev. Semih Lim, 7. Baskı, İstanbul: Yap1 Kredi Yayınları.

HOBBES, Thomas (1998). Leviathan, Introduction, ed. J. C. A. GASKIN, United Kingdom, Oxford: Oxford University Press.

GRAF, Rüdiger (2008). Die Zukunft der Weimarer Republik, München: Oldenbourg Verlag.

KARDEŞ, M. Ertan (2015). Schmitt'le Birlikte Schmitt'e Karşı, İstanbul: İletişim Yayınları.

KERVEGAN, Jean-François (1988). "Politik und Vernünftigkeit: Anmerkungen zum Verhältnis zwischen Carl Schmitt und Hegel”, Der Staat, 3(27): 371-391.

OTTMANN, Henning (1993). "Hegel und Carl Schmitt", Zeitschrift für Politik, 3(40): 233-240.

SCHMITT, Carl (2009). Tarih ve Siyaset Üzerine İki Deneme, çev. Gültekin Y1ldız, İstanbul: Paradigma Yayıncılık.

SCHMITT, Carl (2014a). Parlamenter Demokrasinin Krizi, çev. A. Emre Zeybekoğlu, Ankara: Dost Kitabevi Yayınları.

SCHMITT, Carl (2014b). Siyasal Kavramı, çev. Ece Göztepe, 3. Baskı, İstanbul: Metis Yayınları.

SCHMITT, Carl (2016). Siyasi İlahiyat, çev. A. Emre Zeybekoğlu, Ankara: Dost Kitabevi Yayınları.

SEIFERT, Jürgen (1985). "Theoretiker der Gegenrevolution: Carl Schmitt 18881985”, Kritische Justiz, 2(18): 193-200.

TOPAKKAYA, Arslan (2011). Fichte, İstanbul: Say Yayınları.

TOPAKKAYA, Arslan (2016). Hukuk ve Adalet, Ankara: Adalet Yayınları.

TOPAKKAYA, Arslan (2006). "Hegel'in Hukuk Felsefesinin Ana İlkeleri (Grundlinien der Philosophie des Rechtes) Adlı Eserinde Devletin Kurumsal Yapısının 
Ana Hatlarıla Analizi”, Erzincan Üniversitesi Hukuk Fakültesi Dergisi, X(3-4): 189202.

TOPAKKAYA, Arslan (2007). "Politika Kavramının Farklı Anlamları Üzerine Bir Analiz?”, Maltepe Üniversitesi Fen-Edebiyat Fakültesi Dergisi, 1: 1-12.

TOPAKKAYA, Arslan (2008). "Tarihsel Materyalizm Bağlamında Marx'1 Yeniden Okumak", Uluslararası Sosyal Araştırmalar Dergisi, 1(3): 378-396.

YEŞILÇAYIR, Celal (2017). Ebedi Barış, Pax Romadan Birleşmiş Milletlere, İstanbul: Tezkire Yayınları. 